\title{
Language Policy in Education: Second Official Language in (Technical) Education in Canada and Cameroon
}

\author{
Alain Flaubert Takam ${ }^{1} \&$ Innocent Fassé Mbouya ${ }^{2}$ \\ ${ }^{1}$ Department of Modern Languages, University of Lethbridge, Lethbridge, Canada \\ 2 Department of English, University of Douala, Douala, Cameroon \\ Correspondence: Alain Flaubert Takam, Department of Modern Languages, University of Lethbridge, 4401 \\ University Drive, Lethbridge, Alberta T1K 3M4, Tel: 1-403-329-2561.
}

\author{
Received: March 7, $2018 \quad$ Accepted: May 3, $2018 \quad$ Online Published: May 15, 2018 \\ doi:10.5539/jel.v7n4p20 URL: https://doi.org/10.5539/jel.v7n4p20
}

\begin{abstract}
It should be said from the outset that, apart from Esambe's (1999) MA thesis, no comparative research, to the best of our knowledge, has so far been devoted to the study of language policy in education in both Canada and Cameroon. Yet, these two countries offer a fascinating basis for comparison because English and French (which were instituted at roughly the same time in these two countries) are the two official languages in each country, but the minority status is reversed. This study, which rests on the observation that students from technical training programmes generally underperform or lack interest in their second official language (SOL), aims at comparing the current policies of SOL in education in order to see how both countries' experiences can be mutually informing. To achieve its purpose, this research focuses on the analysis of the policies of official languages (OLs) in education in both countries, specifically regarding technical training programmes. More clearly, language policy in education and SOL education policy as obtained in both countries will be comparatively examined. The comparison, it is hoped, will reveal the fundamental causes of the overall poor performance or lack of interest observed in Cameroon and Canada respectively.
\end{abstract}

Keywords: second official language, French as second language, English as second language, technical education, Canada, Cameroon

\section{Introduction and Background}

The most striking feature Cameroon and Canada share is undoubtedly their two official languages: English and French. In Cameroon, French is the majority official language as the French-speaking population is estimated at $80 \%$. In Canada, however, French is the minority official language. The general figures of the most recent population census show that English is the first or home language for 25.9 million Canadians (74.5\% of the population) while French is first or home language for 8.2 million (23.4\%) (Statistics Canada, 2017). Canada, unlike Cameroon, is a federal country and so her ten provinces and three territories are autonomous in many respects. In terms of education, each province or territory manages its own education and curriculum through district school boards. This is not the case in Cameroon where a centralist policy is applied, even in education. It should also be noted that, in spite of its minority status, English is fast gaining ground in French Cameroon because it has become the dominant world language and so, many free online resources that support the teaching of English as a second language (ESL), English as a foreign language (EFL) and English for Specific purposes (ESP) are available.

In Cameroon, both official languages are used alongside some 260 local languages (Simo Bobda, 2006) while in Canada, the two official languages and about 53 aboriginal languages (Cook, 1998) and countless world languages brought to the country through immigration make up the linguistic landscape. Local languages in Cameroon, like aboriginal languages in Canada, play almost no role in public life and are endangered in various degrees.

Cameroon's two exoglossic and exonormative official languages were inherited from colonisation and have held official status since 1961. The government, since the adoption of this official language policy, has tried to promote and develop them among citizens with results so far considered by many researchers as underperforming (Tchoungui, 1982 \& 1983; Tadadjeu, 1990; Kouega, 1999 \& 2007; Tabi-Manga, 2000; Mbangwana, 2002; Ayafor, 2005; Echu, 2005; Simo Bobda, 2006; Takam, 2007 \& 2012; Fassé, 2012; Echu \& Ebongue, 2012). The sector par 
excellence of state attempts to promote the MOLs has been education where the government has taken several approaches: creation of bilingual schools nationwide; launching of "Opération Bilinguisme" which entailed the teaching of MOL in the last three classes of primary education; extension of the teaching of MOL to the whole primary cycle; increase of the number of hours of MOL in secondary schools; and teaching of MOL made mandatory in all higher education institutions. All these measures, however, have yielded unsatisfying results, poorer ones being recorded in technical education, as Yembe (1989) noticed a few decades ago. Today, 29 years later (2018), the situation remains the same.

In fact, the results of an on-going diagnostic study carried out by Fassé (2017) at the Advanced Teacher Training College for Technical Education (best known by its French acronym ENSET) involving some 80 technical-education and 48 general-education high school graduates newly admitted into the school are very telling. Both groups of students took part A of the Pearson placement test ${ }^{\mathrm{R}}$ which comprises 50 questions and they were equally asked to list ten tools that are used in a typical workshop of the trade into which they had been admitted at ENSET. It is noteworthy that though ENSET is a technical education institution, students of general education, precisely those who hold a GCE "A" Level or Baccalaureate majoring in Mathematics, Physics, Chemistry or Biology are admitted into some specific trades like Civil, Computer and Electrical Engineering. The objective of the placement test was to compare the overall level of English of both groups after a minimum of 7 years of English while the vocabulary exercise aimed at assessing how much technical jargon students of technical education had absorbed. However, even students from general education completed the vocabulary exercise. The placement test results indicated that up to $28.75 \%$ of technical students were below elementary level, $60 \%$ were just Elementary and $11.25 \%$ below intermediate. Students from general education performed better, with only $12.5 \%$ scoring below Elementary, $52 \%$ elementary and up to $35 \%$ below intermediate. Regarding the technical vocabulary exercise, it was quite surprising to see that up to $46 \%$ of technical education students could not even list one workshop tool of their trade with just $12 \%$ scoring above 5 out of 10 . It was not surprising for $46 \%$ of students from general education to score 0 out of 10 as they are not expected to have learnt a technical jargon. These results clearly show the minority official language development in technical education in Cameroon is a serious cause for concern both regarding English in general and ESP in particular.

In Canada, unlike Cameroon, the two official languages are the founding languages of the Confederation. State bilingualism is provisionally applicable since the constitution of the British North America Act of 1867, section 133 of which authorizes the use of the two languages in the parliament, federal courts, archives and federal newspapers. However, for about 100 years after the Confederation, French was not really promoted in English Canada (see for example Hayday, 2005 and Fraser, 2007). In fact, "the best treatment that French-speaking minorities could hope for from their government was benign neglect" (Hayday, 2005, p. 16). It is the Official Languages Act of 1969 which makes the use of English and French compulsory in federal institutions. This law was based on the principles of territoriality (with the exception of New Brunswick, each province is officially monolingual) and personality (citizens get services in either official language no matter where they are). See for example Mackey (1976) for a lengthy development of this aspect. Some provinces and territories have adopted a number of policies and services to protect the MOL (Burnaby, 2008; Canadian Parents for French, 2008; Mackey, 2010 and the other contributors in Morris, 2010). In Ontario, for example, the Office of Francophone Affairs and the French Language Services Commissioner were created to promote and revitalise the French-speaking minority of the province, through the French Language Services Act of 1986.

More generally, since the adoption of the Official Languages Act (1969) and the creation of accompanying bodies such as Bilingualism in Education Program in 1970 (Official Languages in Education Program since 1979), Canadians have had the opportunity to educate their children in the official language of their choice and children have been learning, at various scales, their second official language. Since then, MOLs have been better promoted, although much remains to be done for official bilingualism in the education system, especially in technical training. In fact, various technical schools such as Tollgate Tech in Brantford or Ottawa Tech in Canada's bilingual capital do not offer any FSL lessons. By the same token, in K-12 schools that offer technical and practical or industrial arts courses, many students stop having French lessons after Grade 9.

In Canada, especially in Ontario, after informally observing the teaching of FSL in some secondary schools, and after getting French teachers' comments, we noticed that the majority of students opt out of FSL after Grade 9. This is especially true for technical training students, many of whom do not even take Grade 9 French. In the advanced teacher training college for technical education in Cameroon too, we noticed, among colleagues involved in language teaching in general and ESL teaching in particular, that students from technical high schools performed very poorly as compared to their peers in general education. These observations prompted the following 
question: How do both countries' language policies and planning in education in general and in technical training in particular compare?

To tentatively answer the question above, it was deemed interesting to comparatively examine, after outlining the theoretical grounding of this study, in turn, the official language policies in education and second official language education policies of Cameroon as well as Canada with a focus on technical training programmes.

\section{Language Policy: Theoretical Perspective}

Though one may agree with Fodde $(2002$, p. 13) that "it is not easy to find a definition of the phrase "language policy" in a dictionary nor it is easy to find the same definition in the many books published on the subject or on related topics", it is certain that whoever deals in one way or another with the concept of language policy does it with some understanding of it. This work is no exception. Before outlining the definition of language policy as is understood in this work, it is noteworthy that we will consider it to comprise (as suggested by Spolsky, 2005 \& 2007) three "interrelated but independently describable components: practices, beliefs, and management" (Spolsky, 2007, p. 3), but with a focus on the "management" component which Spolsky in an earlier writing (2004) likens to the more common concept of "language planning". More precisely, we will consider this "planning" aspect of language policy in the sense of Cooper's "acquisition planning" theory which "is directed toward increasing the number of users - speakers, writers, listeners, or readers" (Cooper, 1989, p. 33) of minority languages. Such a planning is equally defined as the "efforts [made] to influence the allocation of users or the distribution of languages/literacies, by means of creating or improving opportunity or incentive to learn them, or both" (Hornberger, 2006, p. 28). In a nutshell, this work will examine the laws, acts or any other measures which Cameroon's and Canada's authorities have taken over the years to increase the number of speakers, hearers, listeners and readers of the second official languages through the domain par excellence of language management (Spolsky, 2007) which is school and, by extension, education. Our theoretical approach thus is more specifically based on language in education planning in the sense of Tollefson (2002), Ferguson (2006) and May \& Hornberger (2008), that is, language planning as it relates to the teaching and learning of minority languages in a bilingual or multilingual context. It is therefore a language planning approach in the context of applied linguistics.

\section{Language Policy in Education in Canada and Cameroon}

In this section of the study, focus is on the planning laws, measures and actions taken by governmental institutions and bodies in Canada and Cameroon in other to regulate and promote second official languages through education, i.e. FSL in Canada and ESL in Cameroon.

\subsection{Second Official Language Policy in Education in Canada}

In Canada, the Official Languages Act of 1969 paved the way for Minority Official Language education and Second Official Language instruction (Note 1), through Bilingualism in Education Program (1970-1979) and Official Languages in Education Program (from 1979). Although education falls under the jurisdiction of each province or territory, the federal government has created the Intergovernmental Cooperation for Second-Language Learning, the aim of which is

$[T]$ o help provincial and territorial governments, directly or through the Council of Ministers of Education, Canada (CMEC), provide the residents of each province/territory with the opportunity to learn English or French as a second language and with opportunities for cultural enrichment through knowledge of the cultures of the other official-language community. (Canadian Heritage, 2013)

The Council of Ministers of Education itself was formed in 1967 by the provincial and territorial ministers responsible for education with the objective of providing "a forum in which they could discuss matters of mutual interest, undertake educational initiatives cooperatively, and represent the interests of the provinces and territories with national educational organizations, the federal government, foreign governments, and international organizations" (Council of Ministers of Education, Canada, 2013, p. 2). The federal government of Canada normally collaborates with the provincial and territorial governments by encouraging and assisting them in consolidating and improving the quality of minority language education and second language instruction. The main ideas of such collaboration can be found in the document entitled Roadmap for Canadian Official Languages 2013-2018 (Canada, 2013). The federal government clearly contributes to the costs incurred by the provinces and territories in the delivery of second language instruction.

However, each province or territory is responsible for its own education. For example, the government of Ontario identifies objectives, develops content, sets priorities and evaluates its programmes for minority language education and second official language instruction (see, for example, Ontario, 2009). As regards the latter, the 
government of Ontario (2013a) drew up an important policy and planning document entitled A Framework for French as a Second Language in Ontario Schools, Kindergarten to Grade 12 (Framework) the main objective of which is "to help school boards and schools in Ontario maximize opportunities for students to reach their full potential in French as a second language (FSL)." It supports the three core priorities for education in Ontario: high levels of student achievement, reduced gaps in student achievement, and increased public confidence in publicly funded education (Ontario, 2013a, p. 3). The Framework rests on the following three goals: (1) increase student confidence, proficiency, and achievement in FSL; (2) increase the percentage of students studying FSL until graduation; (3) increase student, educator, parent, and community engagement in FSL.

Teachers are the key to students' success as they are important role models for students and, in many cases, the only French-language models for their students and possibly the only disseminator of information about French cultures and language. Because of that, "[i]t is essential that French be the language of communication in all classroom interactions so that students receive constant exposure to the language in a variety of situations" (Ontario, 2013 b, p. 13). In the spirit of the new curriculum, they are the ones "responsible for using appropriate and effective instructional strategies to help students achieve the FSL curriculum expectations, as well as appropriate methods for assessing and evaluating student learning" (Ontario, 2013b, p. 12). Such instructional strategies, through action-oriented and communicative approaches, would be based on a differentiated approach to teaching and learning. Hence, students' strengths and needs, their background and prior learning and experiences would be activated for effective instruction and assessment. So, FSL teachers would play a major role in the success or failure of the new curriculum. However, the other stakeholders of the school community have their own role to play for the success of the Ontario new curriculum: students, parents, school principals and community partners.

Students in FSL are the main beneficiaries of the new curriculum. They are encouraged to continuously take responsibility for their own learning, improvement and achievement. This is especially true because mastering "the skills and concepts connected with learning in the FSL curriculum requires ongoing practice, personal reflection, an effort to respond to feedback, and commitment from students. It also requires a willingness to try new activities, take risk in using French, and work respectfully with peers" (Ontario, 2013b, p. 11). Students are also urged to "pursue opportunities outside the classroom to listen to and speak French; seek out recreational reading materials and multimedia works in French [...] to extend their knowledge of the world around them; discuss with their parents what they are reading, writing, and learning" (Ontario, 2013b, p. 12). Therefore, the learning of FSL is supposed to be more concrete and more practical.

As insinuated above, parents/guardians would play a central role in their children's learning of FSL. They would do so by discussing their children's work with them, communicating with their teachers and asking relevant questions about their children's progress, in order to help them directly (if they are knowledgeable in French) or indirectly through French resources and cultural opportunities in the community, etc. (Ontario, 2013b). Because parents "are the primary educators of their children with respect to learning about values, appropriate behaviour, and cultural, spiritual, and personal beliefs and traditions, and they are their children's first role models" (Ontario, 2013 b, p. 12), they should communicate to their children the value and the importance of learning French, the other Canada's official language.

School principals should also play a decisive role in the implementation of the new curriculum by ensuring that appropriate resources are made available for FSL teachers and students, by promoting learning teams and working with FSL teachers to facilitate their participation in professional development activities, by promoting the value and importance of learning French and by encouraging students to participate in such extracurricular activities as student clubs in which French is spoken (Ontario, 2013b, p. 14).

Finally, community partners such as university and colleges, businesses, service groups, and other community organizations "are an important resource for a school's FSL program" (Ontario, 2013b, p. 14). Community volunteers can support French instruction and promote a focus on French inside and outside the school. They could therefore be included as guest speakers in school events, etc.

\subsection{Second Official Language Policy in Education in Cameroon}

For decades, linguists have been decrying the absence of a clear-cut language policy (Simo Bobda \& Tiomajou, 1995) including a body to oversee language practices over the country (Mbangwana, 2002; Kouega, 2007). Such a body would be like the Canada's Office of the Commissioner of Official Languages "whose mandate is to promote Canadian linguistic duality and oversee the full implementation of the Official Languages Act" (Office of the Commissioner of Official Languages, 2016). 
As for the specific case of education, as far back as the early 1980s, Tadadjeu already underscored the absence of a "satisfactory technical and educational process for implementing the official language policy" (1983, p. 117) and, about two decades later, officials of the Ministry of National Education, in a landmark report, equally pointed out "the absence of a body to oversee the practice of bilingualism in our education system (MINEDUC, 2000, p. ii). Indeed, it can be said that in Cameroon, language policy is reduced to two articles: one in the 1996 Constitution and the other in the 1998 Education Orientation Law. The January 18, 1996 Constitution in article 1, section 3, stipulates: "The official languages of the Republic of Cameroon shall be English and French, both languages having the same status. The State shall guarantee the promotion of bilingualism throughout the country. It shall endeavour to protect and promote national languages." The 1998 Education Orientation Law on its part indicates in article 3 that "the State sets bilingualism at all levels of education as a factor of national unity and integration." However, unlike Canada where citizens have the right to file a complaint if they feel that their linguistic rights are not respected (one of the duties of the Office of the Commissioner of Official Languages is to carry out investigations into complaints from the public), no such possibility exists in Cameroon.

The two legal frameworks mentioned above are complemented at institutional level by the existence of an Inspectorate General in Charge of Bilingualism where national as well as regional pedagogic inspectors in charge of bilingualism act like the watchdog for the promotion of OLs in education, be it at primary or secondary education levels. These pedagogic inspectors design the curricula and syllabuses that are implemented in schools.

Two other recent measures, taken by the Ministry in charge of education in favour of official bilingualism development are:

(a) decision number 1141/B1/1464/MINEDUC/IGE/BIL of $28^{\text {th }}$ October 2002 instituting a National Day of Bilingualism in all schools, be they private or public, during which English is expected to be spoken by all Francophones and French by all Anglophones and,

(b) decision number B1/1464/MINEDUC/IGE/PGP/BIL aiming at revamping practical bilingualism in secondary schools with the creation of "English Clubs" for French-speaking students and corresponding Clubs de Français for English-speaking students.

How is all the preceding translated into daily practice in schools, specifically in technical education?

Before answering this question, it should be recalled that technical education is separated from general education after primary school in Cameroon. There are two entry points: the first is for those who opt to join technical education directly after completing primary education; the second is to continue in general education until the end of the first cycle (four years) and then join the second cycle of technical education to spend three additional years. As a subject, the second official language is compulsory in all classes of all cycles. In Canada, however, there is normally no division between general and technical education, even if some tech schools exist. There are three types of courses offered in Ontario high schools: college- and university-bound courses, workplace-bound courses and open courses. This could explain the need for FSP (French for Specific Purposes) for students who take the workplace-bound courses. But the reality is that no tech secondary school we have contacted offers FSL, not even in Grade 9 where this subject is normally compulsory in Ontario. In other schools with arts, science and technology programmes, many students do not seem to take French after grade 9, especially those students who intend to specialize in a technical and vocational programme. It should be mentioned though that students with special needs are often exempted from FSL in Grade 9 in Ontario schools. They can take a course called "Learning Strategies" in lieu of FSL. Such students seem to be overrepresented in technical training programmes in high school. Nevertheless, it will be added that if many students opt out of FSL, it is probably because the system excludes them. For example, FSL is not needed to complete a Specialist High Skills Major (SHSM). SHSM programmes are offered in a good number of High schools in Ontario to students who are interested in pursuing a career path that matches their skills and interests. Their postsecondary destination is likely the apprenticeship, college, the workplace and possibly university.

The promotion of official languages in education in Cameroon, specifically in secondary education, is done through the teaching of second official languages as compulsory subjects with a weekly load ranging between 3 hours and 5 hours in the seven years of secondary and higher education. The major demarcation the government does between the second official language teaching and other subjects is that the former features at all levels and every year in the programme as compulsory subjects. However, no differentiation is made as to didactic material and other teaching/learning parameters that could reflect State's pursuit of generating English-French bilingual citizens through general and technical education. Moreover, one could expect that the specificity of technical education would dictate some peculiarities in the orientation of teaching methods and teaching materials. Unfortunately, the reality is different. Indeed, the same books that appear on the book list for general education 
also appear on that of technical education except that there is a course book series entitled English for Technical Colleges (Note 2) Book 1 to 5 authored by Nduge (2012). Quite surprisingly, the same book appears on list of English books adopted by the Ministry of Secondary Education for Anglophone technical colleges. So, the legitimate question one is entitled to ask is whether or not the authors or the authorities make a difference between English as a first official language (when it is taught to Anglophones) and English as a second official language (when it is taught to Francophones) regarding the pedagogy and didactic materials. Again, given that in technical education it is normally ESP which is needed, one wonders how one single course book could accommodate the specific needs of over 20 specialties found in Cameroon technical education.

The second official language policy in education in Cameroon does not seem to accommodate the specificity of technical education, even if this type of education is unambiguously distinct from general education. A close look at the second official language programmes in the two countries could further enlighten the situation painted in the foregoing section.

\section{Second Official Language Education Policy in (Technical) Education: The Case of French in Canada and English in Cameroon}

\subsection{The Situation in Canada}

The situation in Canada will be examined from three FSL programmes in Ontario schools: core French, Extended French and French immersion, the primary objective of which "is to increase, within realistic and well-defined parameters, a student's ability to communicate in French" (Ontario, 2013b, p. 15).

\subsubsection{Core French Programme}

In elementary schools, Core French is aimed at developing basic communication skills in French, as well as an understanding of the nature of the language and its culture in Canada and beyond. As stated in the new curriculum,

Core French is mandatory from Grades 4 to 8 for all students in English-language elementary schools. Students entering Grade 4 must receive French instruction in every year from Grade 4 to Grade 8 and must have accumulated a minimum of 600 hours of French instruction by the end of Grade 8. Once an instructional sequence has begun, the program must continue uninterrupted to Grade 8 . School boards are encouraged to consider alternative timetabling for Core French program delivery to maximize learning for students. (Ontario, 2013b, p. 15)

However, in a school where an Extended French programme and/or French Immersion programme is/are offered, students may choose to enrol in any of them. At the secondary level, French is taught exclusively as a subject.

\subsubsection{Extended French Programme}

The extended French programme is offered from grade 4 although school boards might choose to start it in a school even after grade 4 . In this case, the school boards must ensure that the policy and programme requirements are met. In this programme,

French must be the language of instruction for a minimum of 25 per cent of the total instructional time at every grade level of the program and provide a minimum of 1260 hours of instruction in French by the end of Grade 8 . The program must include the study of French as a second language and the study of at least one other subject taught in French. That subject must be selected from the following: the arts, social studies (Grades 1 [sic] to 6) or history and geography (Grades 7 and 8), mathematics, science and technology, and health and physical education. Entry points and number of hours for Extended French programs can vary between school districts, allowing for flexibility in program delivery. (Ontario, 2013b, p. 15)

At the secondary level, students take French as a subject, but also as a medium of instruction in at least one other subject. In the Extended French programme, "students accumulate seven credits in French: four are for FSL courses; three are for other subjects in which French is the language of instruction. Schools may grant a certificate in Extended French if the student fulfils these requirements" (Ontario, 2014, pp. 15-16).

\subsubsection{French Immersion Programme}

The French Immersion programme normally goes from grade 1 up to grade 12, even if school boards have the choice to start it at any level in elementary school or in secondary school. In this case, as for the extended French programme, the boards will make sure that students meet the policy and minimum programme requirements outlined below, as well as all the expectations of the programme. More generally, in a French Immersion programme, 
French must be the language of instruction for a minimum of 50 per cent of the total instructional time at every grade level of the program and provide a minimum of 3800 hours of instruction in French by the end of Grade 8. French Immersion programs must include the study of French as a second language and the study of at least two other subjects taught in French. These two subjects must be selected from the following: the arts, social studies (Grades 1 to 6) or history and geography (Grades 7 and 8), mathematics, science and technology, and health and physical education. Although the French Immersion curriculum is written for a Grade 1 start, many immersion programs starting in Grade 1 provide instruction in French in all subjects (i.e., for 100 per cent of total instructional time) until Grade 3 or 4, when students begin to study English. Instruction in English may then be gradually extended to include other subjects. By the end of Grade 8, students may receive up to 50 per cent of their instruction in English. (Ontario, 2013b, p. 16)

At the secondary level, students take French as a subject, but also as a medium of instruction in at least two other subjects. In the French Immersion, "students accumulate ten credits in French: four are for FSL courses; six are for other subjects in which French is the language of instruction. Schools may grant a certificate in French Immersion if the student fulfils these requirements" (Ontario, 2014, p. 16).

More generally, at the secondary level, Extended French and French immersion programmes have one course type each: Academic French (Grades 9 - 10) and University Preparation (Grades 11 - 12). However, in Grades 9 - 10, two types of Core French programmes are offered: Academic and Applied. In Grades 11 - 12, Core French also has two courses at each level: University Preparation and Open. Normally, Academic French and University Preparation are meant for students who intend to go to university after grade 12 whereas Applied French and Open are reserved for students who plan to pursue a technical or vocational programme in a college or who would go for apprenticeship or workplace after high school. However, the latter courses are not based on technical French or, at least, French for specific purposes (FSP). As such, students are generally not instructed in the language of their various trades, whether they take Core French, Extended French or French Immersion, three FSL programmes that are normally supposed "to enable all students to continue to develop their French-language skills whether their post-secondary destination is apprenticeship, college, university, or the workplace" (Ontario 2013a: 4). It remains to be seen if the FSL teachers are trained with this objective in mind, especially for students who opt for technical and vocational programmes in high school or for the workplace after high school. This aspect will be analysed in subsequent papers, in the light of fieldwork results.

\subsection{The Situation in Cameroon}

Unlike Canada where there are three FSL programmes in primary and secondary levels, there is only one ESL in Cameroon (more or less like Core French). However, to examine the situation in Cameroon, it appeared necessary to start by throwing more light on what is understood by technical education in Cameroon's education system. Then the orientation given to English as second official language programme will be examined.

\subsubsection{More on Technical Education in Cameroon}

In fact, post-primary education in Cameroon forks into two: general secondary education and technical education. The latter is divided into two cycles: the first lasts four years and culminates in an end-of-cycle examination best known by its French appellation CAP (Certificat d'aptitude professionnelle); the second ends after three years with students taking the baccalaureate or the General certificate of Education Advanced Level examination. It is noteworthy that technical education equally forks into two major fields: commercial studies and engineering studies. While commercial specialties need what is generally referred to as Business English in ESP terminology, those of the engineering domains need Technical English. Technical education is under the Ministry of Secondary Education (MINESEC). Vocational education on its part is a different matter altogether. It lasts two years after primary education and aims at quickly producing ready-to-serve and young labour force. Special training centres cater for vocational education under the Ministry of Labour and Vocational Training. In the framework of this study, only technical education is dealt with. The MINESEC website provides the following table, which lists out all the 20 specialities available in this type of education. 
Table 1. Specialities offered by Cameroon technical education

\begin{tabular}{llll}
\hline Civil Engineering & Civil Engineering-Practical work & Administrative Techniques & Hospital and Biomedical Maintenance \\
\hline Electrical engineering & Biological & Commercial & Sanitary Installation \\
& Sciences & Techniques & \\
Mechanical engineering & Clothing industry & Quantitative Management & Medical Secretaryship \\
& & Techniques & \\
Industrial Chemistry Engineering & Tourism and Hotel Management & Economic Sciences & Assistant Chemist and Biologist \\
Civil Engineering-Design & Beauty and hair dressing & Home economics & Medico-social Sciences \\
\hline
\end{tabular}

Source: MINESEC website (accessed July 2016).

\subsubsection{English Language Education Programmes in Technical Education in Cameroon}

Concerning syllabuses of English as Second Official Language (ESOL) in Cameroon, it should be noted that, since there is no differentiation between general and technical education in the language policy in education as mentioned above, no fundamental differentiation could be expected at the level of syllabuses either. The only difference appears in general education between science students and art students in the second cycle whereby, while science students will have three hours of English a week, arts ones will receive four hours of teaching, even if they all use the same course books (Note 3). Only major orientations of those syllabuses will be discussed here.

In his discussion of the syllabuses of English in francophone Education in Cameroon, Nkwetisama wrote:

The syllabus of English for Francophone general secondary schools clearly spells out that English language teaching (ELT) is in a state of constant flux and teachers of English have to be abreast with current trends so that products of the system would not sound outdated in what they do with language. The products of the system would have to use language to cope with the many varying situations and contexts in which they find themselves at all times. Language should be taught in such a way that the learners are provided with study skills and strategies to cope with an ever-changing world. (Nkwetisama, 2012, p. 516)

From the preceding quote, it appears that the objectives of those syllabuses are not just very laudable, but they equally warrant a context-specific teaching which integrates learner's needs. Thus, students attending general education and those in technical education would not normally be taught the same content. Regarding the theory behind these syllabuses, Nkwetisama (2012) further remarks:

The underlying theory of language learning adopted by the syllabus is based on the assumption that language learning is intended for communication between/among speakers in various social contexts. The learners do things and get things done with language in specific situations. (Nkwetisama, 2012, p. 517)

Nkwetisama provides thus another indication that the teaching of ESOL in technical education should be ESP-oriented if the objective of the syllabuses and their underlying theory are accommodated by teacher trainers, teachers and didactic material producers. But the reality is a complete different world. Indeed, Focho (2011), who did his field research in francophone secondary schools examining their perceptions of English as a developmental tool in Cameroon, laments:

A good number of teachers fail to be creative in making English language teaching (ELT) dynamic and related to real-life experiences. They are still glued to the textbook, moving from one unit to the next without any attempt to integrate experiential learning or global issues to make learning interesting. Besides, the large class size is a real handicap to the use of various activities, individual attention and effective evaluation. (Focho, 2011, p. 144)

Tendoh (2012), in her comparative study between the teaching of EFL/ESL in Sweden and in Cameroon Francophone education, reached similar disappointing results, as she decries:

In the schools where this study was carried out, the teachers said that grammar is taught at least twice every week, that is in every lesson, time is devoted for teaching grammar, while oral communication seems to have no place. The reason being that, the students are not tested in oral communication both during class and national exams whereas, grammar comprises 30 percent of the grades in writing. Therefore, it is more important for the teacher to spend time explaining grammatical rules in class rather than engaging the students in communicative exercises. (Tendoh, 2012, p. 11)

All in all, ESOL syllabuses, which are meant for both general and technical education indiscriminately, are very interesting and are aimed at developing competent English users at the end of secondary and high school. However, their implementation is where it hurts, whence the conclusions arrived at after fieldwork by the 
authors cited above, who are just a few of the many who have arrived at the same conclusions as to the output of ESOL teaching and learning in Cameroon francophone education.

\section{Conclusion and Prospects}

Cameroon and Canada do share English and French as official languages, but both countries display overt differences in their approach to the promotion of their official languages in education, especially in technical training. However, one striking similarity, which is rather a weakness, is reflected in the two settings.

Regarding differences, at policy level there is a clear-cut and decentralised policy in Canada against a vague and centralised one in Cameroon. At the educational level, there are clear province-specific curricula and syllabuses in Canada against national curricula and syllabuses for Cameroon. However, Cameroon has a clear and distinct post-primary technical education programme and setting against a somewhat mixed general and technical education in Canada.

Regarding second official languages in the educational policy practice, while French classes appear to be optional in some level of education in Canada (in Ontario for example, FSL is optional after Grade 9), English classes are systematically compulsory in Cameroon at all levels of education, including technical education.

The situation in both countries equally shows one very striking similarity. In fact, neither country has integrated the specific second official language needs of technical education students neither in curriculum and syllabus design nor in language teachers training schemes.

Therefore, if Cameroon and Canada consider the specific needs of technical training students in terms of SOLs and integrate these in curriculum and syllabus design, as well as in teacher training, this could probably increase the enthusiasm of tech-oriented students and, ultimately the enrolment rates of students who take both FSL and tech or business classes in secondary schools in Canada. In Cameroon, if such needs are taken into account, the results of technical education students in ESL could be better than what they have achieved so far. Ultimately, basing FSL and ESL teaching and learning in technical training programmes on the specific needs of tech-oriented students could increase academic as well as professional mobility of high school graduates in both countries. This preliminary paper thus paves the way for such works which are forthcoming.

\section{Acknowledgments}

The authors gratefully acknowledge the financial support of the University of Lethbridge's Research Start-Up fund (2014-2017).

\section{References}

Ayafor, I. (2005). Official bilingualism in Cameroon: instrumental or integrative policy? In J. Cohen, K. McAlister, K. Rolstad, \& J. MacSwan (Eds.), Proceedings of the 4th International Symposium on Bilingualism (pp. 123-142). Somerville, MA: Cascadilla Press.

Burnaby, B. (2008). Language policy and education in Canada. In S. May \& N. Hornberger (Eds.), Encyclopedia of language and education (2nd ed.): Vol. 1. Language policy and political issues in education (pp. 331-341). New York: Springer. https://doi.org/10.1007/978-0-387-30424-3_24

Cameroon. (1998). Loi No 98/004 du 14 avril 1998 d'Orientation de l'Éducation au Cameroun. Retrieved from http://www.axl.cefan.ulaval.ca/afrique/cameroun-loi-1998.htm

Canada. (2013). Roadmap for Canada's official languages 2013-2018. Retrieved from http://www.pch.gc.ca/DAMAssetPub/DAM-secLo-olSec/STAGING/texte-text/roadmap2013-2018_136431 3629232_eng.pdf?WT.contentAuthority $=11.0$

Canadian Heritage. (2013). Intergovernmental cooperation. Retrieved from http://www.pch.gc.ca/eng/1267554385203/1254196518840.

Canadian Parents for French (Ontario). (2008). French second language education in Ontario: Report and recommendations to the Ontario Minister of Education. Mississauga: Canadian Parents for French. Retrieved from http://www.dsb1.edu.on.ca/boardinfo/files/fiwc/CPF-Report-Recommendations.pdf

Cook, E.-D. (1998). Aboriginal languages: history. In J. Edwards (Ed.), Languages in Canada (pp. 125-143). Cambridge: Cambridge University Press. https://doi.org/10.1017/CBO9780511620829.008

Cooper, R. (1989). Language planning and social change. Cambridge: Cambridge University Press.

Council of Ministers of Education, Canada (the). (2013). Pan-Canadian progress report: protocol for agreements on minority-language education and second-language instruction. Toronto: Cemec. 
Echu, G. (2005). The immersion experience in anglophone primary schools in Cameroon. In J. Cohen, K. McAllister, K. Rolstad, \& J. MacSwan (Eds.), Proceedings of the $4^{\text {th }}$ international symposium on bilingualism (pp. 643-655). Somerville, MA: Cascadilla Press.

Echu, G., \& Ebongue, A. E. (Eds.). (2012). Cinquante ans de bilinguisme officiel au Cameroun/Fifty years of official bilingualism in Cameroon. Paris: L'Harmattan.

Esambe, C. A. (1999). Patterns of State bilingualism: A comparative study of Canada and Cameroon. Unpublished M.A. dissertation, University of Yaoundé 1.

Fassé, M. I. (2012). Revamping school bilingualism in Cameroon primary education: some strategies to avoid another failure. Sino-US English Teaching, 9(12), 1754-1759.

Fassé, M. I. (2017). After seven years of English classes in Secondary Education in Cameroon: a comparative study of the achievements of the current practice of ELT in Technical and General education High Schools. The language unit of the Department of Education Sciences, ENSET, University of Douala.

Ferguson, G. (2006). Language planning and education. Edinburgh: Edinburgh University Press.

Focho, G. N. (2011). Student perceptions of English as a developmental tool in Cameroon. In H. Coleman (Ed.), Dreams and realities: Developing countries and the English language (pp. 137-159). London: British Council.

Fodde, M. (2002). Race, ethnicity and dialects: Language policy and ethnic minorities in the United States. Milano: Franco Angeli.

Hayday, M. (2005). Bilingual today, united tomorrow. Montreal \& Kingston: McGill-Queen's University Press.

Hornberger, N. (2006). Frameworks and models in language policy and planning. In T. Ricento (Ed.), An introduction to language policy: Theory and method (pp. 24-41). Malden: Blackwell Publishing.

Kouega, J. P. (1999). Forty years of official bilingualism in Cameroon. English Today, 15(4), 38-43. https://doi.org/10.1017/S0266078400011251

Kouega, J. P. (2007). Bilingualism at tertiary level education: The case of the University of Yaounde II (Soa). In Proceedings of the 6th international symposium on bilingualism, University of Hamburg. Retrieved from http://www.isb6.org/static/proceedings/kouega.pdf

Mackey, W. F. (1976). Bilinguisme et contact de langues. Paris: Klincksieck.

Mackey, W. F. (2010). The history and origins of language policies in Canada. In M. Morris (Ed.), Canadian language policies in comparative perspectives (pp. 18-66). Montréal \& Kingston: McGill-Queen's University Press.

May, S., \& Hornberger, N. H. (Eds.). (2008). Encyclopedia of language and education (2nd ed.): Vol. 1. Language policy and political issues in education. New York: Springer.

Mbangwana, P. N. (2002). Le bilinguisme camerounais: Une juxtaposition linguistique? A paper presented at a seminar during the 2002 Commonwealth week's celebration in the University of Yaoundé I.

MINEDUC. (2000). Final report on the reinforcement of bilingualism in the Cameroon education systems. An unpublished report produced by experts commissioned by the Ministry of National Education.

Morris, M. (Ed.). (2010). Canadian language policies in comparative perspectives. Montréal \& Kingston: McGill-Queen's University Press.

Nduge, A. (2012). English for technical colleges. np: ANUCAM.

Nkwetisama, C. M. (2012). The competency based approach to English language education and the walls between the classroom and the society in Cameroon: Pulling down the walls. Theory and Practice in Language Studies, 2(3), 516-523. https://doi.org/10.4304/tpls.2.3.516-523

Office of the Commissioner of Official Languages. (2016). Official website. Retrieved from http://www.officiallanguages.gc.ca/en

Ontario. (2009). The Canada - Ontario agreement on minority education and second language instruction 2009-10 to 2012-13. Retrieved from http://www.edu.gov.on.ca/eng/amenagement/ententeAgreementEd.pdf

Ontario. (2013a). A framework for French as a second language in Ontario schools, Kindergarten to Grade 12. Retrieved from http://www.edu.gov.on.ca/eng/amenagement/frameworkFLS.pdf 
Ontario. (2013b). The Ontario curriculum: French as a second language. Retrieved from http://www.edu.gov.on.ca/eng/curriculum/elementary/fs118-2013curr.pdf

Ontario. (2014). The Ontario curriculum Grades 9 to 12: French as a second language. Retrieved on January 22, 2015, from http://www.edu.gov.on.ca/eng/curriculum/secondary/fs1912curr2014.pdf

Simo Bobda, A. (2006). Life in a Tower of Babel without a language policy. In M. Pütz, J. Fishman, \& N. Aertselaer (Eds.), 'Along the road to power': Explorations of empowerment through language (pp. 357-372). Berlin/New York: Mouton de Gruyter. https://doi.org/10.1515/9783110923247.357

Simo Bobda, A., \& Tiomajou, D. (1995). Integrating ESL and EFL: The Cameroon Experience. In Proceedings of the West African English language conference (pp. 60-83). Mbour, Senegal: The Bristish Council in West Africa.

Spolsky, B. (2004). Language policy. Cambridge, U.K. and New York: Cambridge University Press.

Spolsky, B. (2005). Language policy. In J. Cohen, K. McAllister, K. Rolstad, \& J. MacSwan (Eds.), Proceedings of the $4^{\text {th }}$ international symposium on bilingualism (pp. 2152-2164). Somerville, MA: Cascadilla Press.

Spolsky, B. (2007). Towards a theory of language policy. Working Papers in Educational Linguistics, 22(1), 1-14.

Statistics Canada. (2017). English, French and official language minorities in Canada: Census of Population, 2016.

Retrieved

from http:/www12.statcan.gc.ca/census-recensement/2016/as-sa/98-200-x/2016011/98-200-x2016011-eng.pdf

Tabi-Manga, J. (2000). Les politiques linguistiques du Cameroun: essai d'aménagement linguistique. Paris: Karthala.

Tadadjeu, M. (1983). Prospects for language planning studies in Cameroon. In E. Koenig, E. Chia, \& J. Povey (Eds.), A Sociolinguistic Profile of Urban Centers in Cameroon (pp. 117-124). Los Angeles: Crossroads Press.

Tadadjeu, M. (1990). Le Défi de Babel au Cameroun. Yaoundé: Université de Yaoundé.

Takam, A. F. (2007). Bilinguisme officiel et promotion de la langue minoritaire en milieu scolaire: Le cas du Cameroun. Revue électronique internationale du langage SudLangue, 7, 26-48.

Takam, A. F. (2012). Politiques linguistiques et gouvernementalité au Cameroun: quelques enseignements tirés de la résistance ethnolinguistique au Canada. In G. Echu \& A. E. Ebongue (Eds.), Cinquante ans de bilinguisme officiel au Cameroun/Fifty years of official bilingualism in Cameroon (pp. 43-64). Paris: L'Harmattan.

Tchoungui, G. (1982). Bilingualism in Cameroon: historical perspectives and assessment 1960-1980. In R. Santerre \& C. Mercier-Tremblay (Eds.), La quête du savoir. Essais pour une anthropologie de l'éducation camerounaise (pp. 753-794). Montréal: Les Presses de l’Université de Montréal.

Tchoungui, G. (1983). Focus on official bilingualism in Cameroon: Its relationship to education. In E. Koenig, E. Chia, \& J. Povey (Eds.), A Sociolinguistic Profile of Urban Centers in Cameroon (pp. 93-115). Los Angeles: Crossroads Press.

Tendoh, C. I. (2012). Similar syllabuses-different didactics and different results: A comparative study of students learning English as a foreign language in Sweden and Cameroon. University of Gothenburg, Gothenburg, Sweden. Retrieved from http://www.ens.cm/index.php/departements/lettres/departement-d-anglais

Tollefson, J. (2002). (Ed.). Language policies in education: Critical Issues. Mahwah, NJ: Lawrance Erlbaum.

Yembe, T. (1989). Attitudes and motivation of francophone technical secondary school students in the learning of English: A case study of Lycée Technique Bafoussam. Unpublished DIPES II dissertation, ENS Yaoundé.

\section{Notes}

Note 1. In Canada, minority official language education is the education received in French by French-speaking people or in English by English-speaking people in a minority context. For example, in Ontario, minority language education is offered entirely in French to Francophones. On the other hand, Second Official Language instruction is the teaching of the second official language, that is, French to Anglophones and English to Francophones. In this paper, we are dealing with the second official langue instruction exclusively.

Note 2. It is worth indicating that the use of the term college can be confusing in Cameroon as it sometimes refers to secondary education, i.e. post primary education like the Presbyterian Christian College Mankon and 
other times to post secondary education like the Advanced Teacher Training College for Technical Education, a university-level institution. However, in Canada, a college will always refer to a post-secondary education institution.

Note 3. The idea behind this difference is that art series students have languages as majors and thus have denser syllabuses that require more time to cover while those of science series rather have scientific subjects as majors and more time is devoted to these.

\section{Copyrights}

Copyright for this article is retained by the author, with first publication rights granted to the journal.

This is an open-access article distributed under the terms and conditions of the Creative Commons Attribution license (http://creativecommons.org/licenses/by/4.0/). 